\title{
EU og undtagelserne
}

Den ny Lissabon-traktat blev formelt undertegnet af EU's stats- og regeringschefer den 13. december 2007. Traktaten fyldte ikke meget i valgkampen forud for det danske folketingsvalg den 13. november, da der var bred politisk enighed om den, og allerede den 11. december meddelte statsminister Anders Fogh Rasmussen, at traktaten ikke ville blive sendt til folkeafstemning. En beslutning som blev bakket op af Socialdemokraterne. Det ser således ud til, at det kun er irerne, der får lov at stemme om Lissabon-traktaten.

Til gengæld kan vi belave os på at skulle stemme om en eller flere af de snart 15 år gamle danske EU-undtagelser. Såvel i regeringsgrundlaget (se Udenrigs side 98-104) som i statsministerens redegørelse i Folketinget den 27. november 2007 blev det understreget, at tiden er løbet fra undtagelserne, der forhindrer Danmark i at deltage i vigtige dele af EUsamarbejdet, og at befolkningen bør have lejlighed til at tage stilling til dem ved en folkeafstemning. Budskabet blev gentaget i nytårstalen, hvor statsministeren understregede, at "Danmark ikke er med i hjertet af Europa" og at undtagelserne bør afskaffes, fordi de "afskærer Danmark fra at spille den rolle i Europa, som vi ellers kunne som ét af Europas mest velfungerende samfund".

Vi kender rumlen: Gamle mod- standere - ikke alene mod euroen, forsvarssamarbejdet og det retlige samarbejde, men mod selve fællesskabet - vil melde sig med bekymring for dansk suverænitet. Tøvende tilhængere vil foretrække at lade den aktuelle statsminister forklare, hvorfor Danmark skal deltage i EUmed-det-hele, og Regeringen, De Radikale og Socialdemokraterne kan for en tid ventes at lade deres uoverensstemmelser vige til fordel for enighed om, at forbeholdene ikke tjener Danmarks interesser.

Udenrigs går i dette nummer ind $\mathrm{i}$ debatten. Erik Boel præsenterer den ny Lissabon-traktat og stiller skarpt på det retlige forbehold, Henrik Larsen fokuserer på det sikkerhedspolitiske samarbejde og forsvarsforbeholdet og Peter Nedergaard på ØMU'en. Uffe Østergård ser på Europa-Parlamentet og Erling Bjøl på begrebet folkeafstemninger og vælgerbefolkningernes mange og forskellige motiver for at stemme.

Vi i EU stemmer ikke ved det amerikanske præsidentvalg, men udfaldet har stor betydning for os. Starten på præsident-valgkampagnen blev dramatisk med Barack Obamas klare sejr over Hillary Clinton i Iowa. Michael Ehrenreich tilbyder en vejviser til de amerikanske primærvalg.

\section{Redaktionen}

